\title{
Reared fish, farmed escapees and wild fish stocks - a triangle of pathogen transmission of concern to Mediterranean aquaculture management
}

\author{
P. Arechavala-Lopez ${ }^{1, *}$, P. Sanchez-Jerez ${ }^{1}$, J. T. Bayle-Sempere ${ }^{1}$, I. Uglem $^{2}$, \\ I. Mladineo ${ }^{3}$ \\ ${ }^{1}$ Department of Marine Sciences and Applied Biology, University of Alicante, PO Box 99, 03080 Alicante, Spain \\ ${ }^{2}$ Norwegian Institute of Nature Research, Tungasletta 2, 7485 Trondheim, Norway \\ ${ }^{3}$ Institute of Oceanography and Fisheries, PO Box 500, 21000 Split, Croatia
}

\begin{abstract}
Although aquaculture in the Mediterranean is a relatively young industry, finfish diseases have been reported to cause considerable problems and mortalities among the farmed stocks. In general, the farming activity and the open design of Mediterranean aquaculture systems allow the transmission of infectious pathogens within and among farm facilities. Fish health and biosecurity programmes at farms have focused on the most obvious pathways for transmission of pathogens, i.e. through transport of infected farmed fish from hatcheries, infected equipment, staff and vessels, as well as through water currents. However, little attention has been devoted to the potential risk of pathogen and disease transmission in Mediterranean open-sea aquaculture through movements of fish. The present study focuses on the importance of considering possible pathogen transmission between reared fish, farmed escapees and farm-aggregated fish when making management decisions.
\end{abstract}

KEY WORDS: Disease - Propagation - Open-sea cages · Sustainability · Ecosystem health · Consumers

\section{INTRODUCTION}

The volume of global finfish aquaculture production, as well as the range of species farmed, has increased significantly during the last 2 decades (FAO 2011). For instance, more than 15 euryhaline marine fish species are now cultured in the Mediterranean basin. The most important cultured species are gilthead sea bream Sparus aurata and European sea bass Dicentrarchus labrax. In 2010, the total production of sea bream and sea bass was approximately 140000 and 120000 t, respectively (FAO 2011). In order to facilitate further production increases, prevention of infectious diseases in farm stocks is important (Salama \& Murray 2011). This will implicitly reduce the potential for significant economic losses through mortality, costs of treatments and carcass removal, or decreased growth rate of moribund and convalescent fish (Murray \& Peeler 2005). Despite a growing fish farming industry and accompanying research efforts, the general fish health status in Mediterranean aquaculture has been considered to have deteriorated in recent years (Subasinghe 2009). The scientific and legislative efforts to ameliorate this situation are apparently not sufficient to prevent disease propagation. Also, there is a considerable lack of empirical knowledge regarding the mechanisms that trigger disease transfer, as most of 
the epizootiological risk assessment studies of disease transmission in aquaculture have been simulated theoretically without experimental or in situ testing under farming conditions (Peeler et al. 2006).

The rapid expansion of fish farming into new areas might involve propagation of 'old' pathogens from the environment to the new cultured stocks, while new environmental conditions may favour growth and expansion of pathogens already present within the new farm stock. For example, in order to produce new and diversified products, novel species are introduced to existing rearing systems, imposing rearing pressure on new fish species inclined to immunosuppression. Under such conditions, bidirectional pathogen transfer is highly possible (e.g. from the new species to the environment and vice versa), since new stocks represent a susceptible focal point of pathogen proliferation. Secondly, the intensification of fish culture, through increased production per farm unit, might also increase the concentration of pathogens within cages and thus facilitate their spreading (Murray 2009), aided by fish immunosuppression resulting from a general adaptation syndrome in intensive rearing (Ashley 2007). In consequence, pathogen concentration in the surrounding environment can increase with the increased numbers of infected fish on a farm, irrespective of their density (Murray 2009).

Disease problems may arise because the current farming techniques and the open design of Mediterranean aquaculture systems permit transmission of pathogens among pens. The primary route for introduction of pathogens to a farm is through transport of infected seedlings from hatcheries (Piper et al. 1982), food, infected equipment, staff and vessels (e.g. Kennedy \& Fitch 1990, Ruiz et al. 2000, Murray \& Peeler 2005), as well as through water currents (Fouz et al. 2000, Amundrud \& Murray 2009, Frazer 2009, Salama \& Murray 2011). Monitoring of animal health, biosecurity programmes and other disease control measures, including disease management areas or surveillance zones around farms in site selection programmes, are designed to minimize the risk of spreading disease through these pathways (DAFF 2000, Scottish Executive 2000, Rae 2002, Subasinghe et al. 2004, Bondad-Reantaso \& Subasinghe 2008, Lyngstad et al. 2008, Mardones et al. 2009, Marine Scotland 2010). The European Community basic legal provision 'Council Directive 2006/88/EC' lays down the minimum prevention, control and eradication measures for aquatic animal diseases to be implemented in aquaculture activity by the Member States. However, the efficiency depends on farmers following the rules. Although disease control regulations for the Mediterranean finfish aquaculture industry are well established (Le Breton 1999, Rodgers \& Basurco 2009), the current legislation is not consistent throughout the Mediterranean (Cardia \& Lovatelli 2007). For instance, seedling import/export regulations and quarantine measures still vary from country to country.

In addition to the 'traditional' pathways for disease transmission, movements of both wild fish and farm escapees also need to be considered as vectors for disease propagation (Fig. 1). This has been studied in more temperate regions of the world (e.g. Diamant et al. 2004, Naylor et al. 2005, Raynard et al. 2007, Johansen et al. 2011), but not in the Mediterranean. The aim of the present study is to discuss the potential risk of pathogen transmission in Mediterranean open-sea aquaculture through movements of escapees and farm-aggregated fish, and we suggest that this should be taken into account in management strategies to ensure the sustainability of aquaculture activity in Mediterranean countries.

According to the World Organization for Animal Health (OIE 2012: www.oie.int/international-standardsetting/aquatic-manual/access-online/), the most frequent Mediterranean pathogens belong to secondary microorganisms that are firmly ingrained at the farm site and emerge periodically, triggered by shifts in environmental conditions or anthropogenic stress.

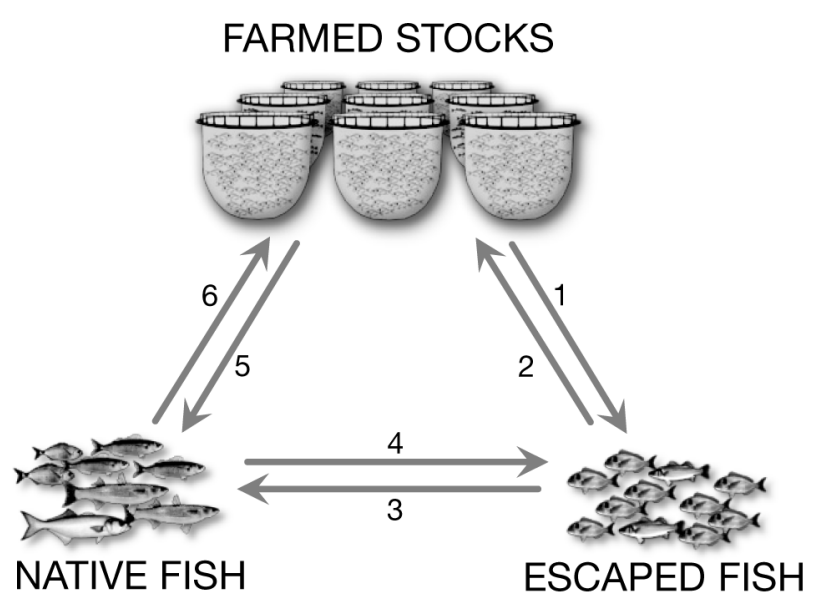

1. Infected escapees as vectors of transmission

2. Movements of escapees among farms

3. Dispersion of escapees to native coastal areas

4. Infection of feral escaped fish with native pathogens

5. Spread of pathogens to farm-aggregated wild fish

6. Movements of infected wild fish among farm facilities

Fig. 1. Generalized flow chart of potential pathogen transmission through movements of wild fish and escapees 
These 'domestic' pathogens are able to infect farmed stocks but are also present in the farm even when no clinical symptoms are observed. Such local diseases may perhaps be the most probable candidates for propagation through escaped fish as they are treated according to farmers' experience, which in turn may increase the risk for development of resistant strains.

\section{ESCAPEES AS POTENTIAL VECTORS OF TRANSMISSION}

A characteristic of net-pen production units is that fish may escape from the pens (Johansen et al. 2011). Over 7 million farmed sea bream and sea bass have been reported to have escaped from Mediterranean farms in 67 small- and large-scale incidents (Jackson et al. 2012). Escapees may significantly alter the temporal or spatial distribution of pathogens occurring in farms and in the wild. Apart from the pathogen characteristics and level of fish infection within the farms, the risk of disease propagation depends on survival and post-escape behaviour of the escapees, as well as the wild fish abundance outside farms. However, the health status of escapees and the viability/pathogenicity of their putative pathogens have yet to be examined in the Mediterranean.

Several studies on escaped sea bream and sea bass in the south-western Mediterranean Sea have demonstrated connectivity among farms and other marine areas of interest, like local fishing grounds (Arechavala-Lopez et al. 2011b, 2012). These findings indicate a risk of spreading diseases and pathogens through movements of escapees, both to other farms and wild fish populations. Farmed sea bream and sea bass share many pathogens with their wild conspecifics and other wild fish species, which also increases the risk of pathogen transmission (Raynard et al. 2007). Therefore, the dispersion of farm-escaped fish should be taken into account in disease control programmes.

Although there are no regulatory measures established in Mediterranean aquaculture to reduce the risk of fish escape, these do exist in several other countries (i.e. Canada, Norway, USA, Chile, Scotland). These strategies have increased our knowledge about pathogen transmission through escapees, in particular for salmonids (e.g. Heuch \& Mo 2001, Krkošek et al. 2005, Naylor et al. 2005, Ford \& Myers 2008, Thorstad et al. 2008, Revie et al. 2009, Jensen et al. 2010, Johansen et al. 2011). For instance, escaped Atlantic salmon have been identified as reservoirs of the parasitic sea lice Lepeoph- theirus salmonis in coastal waters (Heuch \& Mo 2001, Revie et al. 2009), and escapees may spread lice to wild fish populations (Johnsen \& Jensen 1994, Graham 2005, Plarre et al. 2005). Moreover, transmission of pathogens and parasites from farmed fish or escapees to wild populations may also occur in farming of Atlantic cod Gadus morhua (Øines et al. 2006, Hansen et al. 2008). In addition, connectivity among cod farms through movements of escapees has been demonstrated (Uglem et al. 2008,2010 ), although direct evidence for transfer of pathogens is lacking at present. With the exception of salmon lice, knowledge about transmission of pathogens from cod and salmon farming to wild fish is limited (Johansen et al. 2011). However, the actual risk of disease transmission from cod farms is currently very low, as the cod farming industry in Norway is severely reduced due to lack of economic viability. Heuch et al. (2011) suggested that trophically transmitted parasites (larval nematodes, digenean metacercariae, cestodian plerocercoids) are the most unlikely to become a health problem for farmed cod, compared to those parasites with simple life cycles and pelagic transmission stages, such as monogeneans and trichodinids, whose direct life cycle is strongly influenced by environmental conditions (temperature, salinity, organic matter). Nonetheless, the latter parasitic groups can easily lead to marketability issues due to noticeable skin infections on farmed fish.

\section{CROSS-CONTAGION BETWEEN FARMED AND NEIGHBOURING WILD FISH STOCKS}

It is difficult to evaluate the health effect of escapees on the ecosystem without taking into consideration the qualitative aspects of wild fish assemblages around farms. A range of studies have shown that farms act as fish aggregating devices (for a review, see Sanchez-Jerez et al. 2011). The influence of farms on wild fish, such as diet modification, may be detrimental for some parasite species, while these same conditions could enhance others (FernandezJover et al. 2010). A wide range of pathogens can be found in a large number of farm-aggregated wild fish (Raynard et al. 2007). Cross-contagion between farmed and wild fish species with shared pathogens may occur (Diamant et al. 2004, 2007) either through movements of individual fish or through speciesspecific migrations (Horbowy \& Podolska 2001, Butler 2002, Murray et al. 2003, Murray \& Peeler 2005, Krkošek 2010). Connection among farms and other 
marine areas of interest through wild fish movements have been demonstrated both in Norway (Uglem et al. 2009) and in Mediterranean fish farms. For instance, 2 grey mullet species (Liza aurata and Chelon labrosus) were shown to aggregate beneath cages, feeding on waste fish food, and moving among different farming and coastal areas (Arechavala-Lopez et al. 2010). In addition, farm-aggregated bogue Boops boops were found within local fisheries landings from the nearby fishing grounds (Arechavala-Lopez et al. 2011a).

Although these wild fish species share a large number of pathogens with farmed sea bream and sea bass, knowledge regarding the potential for pathogen transfer is not unambiguous. For example, in 2 Croatian farms, the polyopisthocotylean monogenean Sparicotyle chrysophrii and the cymothoid isopod Ceratothoa oestroides have both been isolated simultaneously from farmed sea bream, sea bass and wild bogue. However, analysis of the mitochondrial DNA marker cytochrome oxidase I (mtDNA COI) demonstrated that parasites inhabiting different hosts did not belong to the same population, but cluster separately, evidencing that no transfer of 2 parasite species occurred between wild and farmed fish (Mladineo et al. 2009). Interestingly, another monopisthocotylean monogenean, Frurnestinia echeneis, which has only recently been found to colonize farmed sea bream (Mladineo et al. 2010), has been genetically identified (mtDNA COI and internal transcribed spacer 1, ITS1, with partial 18S and 5.8S ribosomal DNA) as a shared parasite between farmed and wild sea bream (Mladineo et al. in press). However, only a minor proportion of parasite haplotypes were shared between the 2 fish populations. Moreover, when monogenean-free fingerlings were introduced to cages, they became infected by monogenean haplotypes from the farmed bream parasite population (I. Mladineo et al. unpubl. data).

Therefore, although the distribution of fish pathogens and their pathogenicity, prevalence and incidence in wild populations must be taken into account when developing a proper disease management programme (McVicar 2004, Johansen et al. 2011), many conditions must be fulfilled before pathogen transmission takes place. It seems, however, that the transfer is more likely to occur, even for generalist parasite species, if fish are in close vicinity, as well as if the hosts (e.g. farmed and wild) are of the same species. Farming conditions (oceanography of the site, density on both sides of the net-pen) further contribute to the transfer chances, but should be carefully assessed case by case before drawing conclusions.

\section{POTENTIAL PATHOGENS IN MEDITERRANEAN FARMED AND WILD FISH}

A wide range of virus, bacteria and parasite species have been described from both wild and cultured sea bass and sea bream, some of which have negative economic impacts for the fish farming industry. Most bacteria and viruses are transmitted horizontally through water or individual contact (Raynard et al. 2007), but vertical transmission through ovarian and seminal fluids also occurs (Romalde et al. 1999). In addition, vertical transmission from infected broodstock to offspring has been indicated as a dispersal route in farmed sea bream and sea bass (Castric et al. 2001, Breuil et al. 2002).

Knowledge about transfer pathways for individual pathogens, and in particular for viruses, is very sparse. However, Panzarin et al. (2012) showed that transfer of Betanodavirus between wild and farmed fish is possible, since viruses isolated from feral and farmed fish in some cases were found to be similar. Infections caused by pathogens that are shared by both farmed and wild fish are stress-related, and derived diseases usually occur at high stocking densities (Raynard et al. 2007). Skin condition also plays an important role in the onset of some bacterial diseases, since skin lesions act as sites of pathogen entry (Raynard et al. 2007). For instance, Tenacibaculum maritimum, Vibrio algynolyticus and Mycobacterium marinum are associated with stress conditions and disruption of fish skin integrity after handling (Colorni \& Diamant 1992, Balebona et al. 1998, Toranzo et al. 2005).

Monogenean parasites, inhabiting skin, gills, external body cavities and the urogenital apparatus, might induce proliferation of secondary bacterial infection between hosts (Mladineo 2002). These parasites also include generalist species, which increase the possibility of transfer between farmed and wild fish (Wootten 1989, Sasal et al. 2004). For more specialised species, host-specificity may be lost in aquaculture (Noga 2000). For instance, Mladineo \& Maršić-Lučić (2007) reported host switch of 2 monogenean species, Lamellodiscus elegans and Sparicotyle chrysophrii, between cage-reared sparids, sea bream and sharpsnout bream Diplodus puntazzo, indicating a broadened host range. Moreover, recent colonization of farmed sea bream by the 'new' monogenean species Furnestinia echeneis that suppressed the generalist $L$. elegans from the same host, indicate that a novel pathogen has been transferred from the wild or has been imported by bream fingerlings. Transfer from the wild is plausible, since the genetic 
framework of $F$. echeneis populations in the farmed host originated from ancient haplotypes present in the wild (I. Mladineo et al. unpubl. data).

In addition, high stocking provides optimal conditions for isopod parasites. The most common isopod parasite, Ceratothoa spp., primarily isolated from farmed sea bass and sea bream, has become a problem in Mediterranean cage aquaculture (Athanassopoulou et al. 2001, Papapanagiotou \& Trilles 2001, Mladineo 2003, Bouboulis et al. 2004). It has been demonstrated that infective stages of the isopode (pulli) have a time-limited natatory potential after being released from the female (Mladineo \& Valić 2002, Mladineo 2003), indicating that as the distance between hosts decreases, or fish density increases, the infection rate of the parasite increases. However, none of the cymothoid species reported on farmed bass and bream are known to parasitize wild conspecifics, although they occur on wild congenerics (e.g. sparids). While wild marine fish are hosts to a wide range of parasites, sometimes the dominant parasite in culture is either rare or absent in the same species in the wild, but if the dominant parasite species in aquaculture is present in wild fish populations, adverse effects are more obvious in farmed fish (Nowak 2007). Nevertheless, the assumption that farms amplify pathogen number has recently been shown not to be valid in tuna (Mladineo et al. 2011). Although tuna farming is capture-based and relies on juvenile and adult wild tuna in contrast to sea bream/bass farming, the latter authors observed the disappearance of monoxenous copepods and monogenean species with direct life cycles, as well as a significant decrease of heteroxenous digeneans propagated through trophic pathways. Mladineo et al. (2011) concluded that it is difficult to postulate the combination of factors affecting these parasite populations, but environmental, anthropogenic or host intrinsic influences have to be taken into account. This finding suggests that no general rule can be applied for every aquaculture system, fish species or inhabiting parasite community, and that strict disease management plans are important.

A large number of myxozoan species have also been shown to infect farmed sea bream and sea bass, but the exact transmission patterns are unknown in most of the reported cases. For instance, Sphaerospora testicularis, which occurs in male gonads of sea bass and can cause complete destruction of the organ (Alvarez Pellitero \& Sitjà-Bobadilla 1993, Rigos et al. 1999), has been detected in wild, farmed and escaped sea bass (e.g. Sitja-Bobadilla \& Alvarez Pellitero 1993, Toledo-Guedes et al. 2012) but cross- contagion has not been demonstrated. However, it is suggested that $S$. testicularis-infected escapees could alter the reproduction dynamics of local populations after mass escape events (Toledo-Guedes et al. 2012). The sparid myxidiosis agents Enteromuxum scophthalmi, E. leei, Myxidium fugu and Myxidium sp. are transmitted spontaneously between fish (Redondo et al. 2004), and it is possible that wild fish act as reservoirs of this disease (Raynard et al. 2007). Due to low specificity, ease of fish-to-fish transmission and high pathogenic potential, sparid myxidiosis poses a serious risk both for farmed and feral fish communities (Raynard et al. 2007).

Transmission of bacterial diseases among wild grey mullets (e.g. Mugil cephalus, Chelon labrosus, Liza spp.) and sparids (e.g. Boops boops, Sarpa salpa, Diplodus spp.) and farmed fish is well documented. For example, transmission of Streptococcus iniae and Mycobacterium marinum from sea cages to wild fish in the Mediterranean and Red Sea has been confirmed (Diamant et al. 2000, Colorni et al. 2002, Ucko et al. 2002, Kvitt \& Colorni 2004). Furthermore, the same strain of $S$. iniae identified from infected farmed fish was isolated from wild fish as far as $2 \mathrm{~km}$ from the cages (Colorni et al. 2002), and the same strain of $S$. agalactiae was isolated from cultured sea bream and wild mullet Liza kluzingeri in the Arabian Gulf (Evans et al. 2002). Unlike parasitic pathogens, bacteria seem to have a higher potential to spread between wild and farmed fish, probably because the ecological barriers that exist for parasite transfer do not represent a great obstacle for bacteria. Firstly, bacteria are almost always present on fish surfaces. Secondly, bacterial diseases are usually treated by non-professional staff at the farms, consequently involving increased risk of developing resistance and more pathogenic strains. Finally, bacteria are often generalists and do not need wild conspecifics to spread from farmed fish.

\section{GUIDELINES AND CONCLUSIONS}

There is a potential risk of pathogen transmission through movements of escaped and wild fish in Mediterranean fish farming areas, but actual transmission has been documented only in a handful of cases. Infected farmed fish that escape from cages by technical or operational failures may in theory spread pathogens to other cages/farms, as well to wild fish (Arechavala-Lopez et al. 2011b, 2012). In addition, infected wild fish might transfer pathogens back to the farmed fish, or become infected by farmed stocks if they stay close to farms (Raynard et al. 2007). More- 
over, the large variety of shared pathogens among wild and farmed fish and the various pathways of pathogen transmission increase the potential for infection and render epidemiological risk management difficult. Therefore, disease outbreaks at farms could facilitate the transmission of pathogens from fish which are held in great numbers in cages and can easily be dispersed through water currents and aforementioned fish movements, finding a potential host. Further research on molecular mechanisms of disease transmission in aquaculture and marine environments, as well more holistic analyses of pathogenic events in the Mediterranean, are needed to clarify the potential of transmission of pathogens from aquaculture to the marine ecosystems.

As Mediterranean aquaculture is expected to increase in the future, actions that reduce the risk of disease emergence, establishment and spread are required. There are several factors involved in pathogen transmission that should be taken into account in this context, for example host density, pathogen-host specificity, proliferation of disease and environmental characteristics. As for other forms of animal health management, preventive measures are the most effective, cost efficient and long lasting (Meyer 1991). Firstly, improving biosecurity and disease control programmes is necessary at all levels of the fish farming industry, from the production unit to markets, in order to prevent and control diseases and preserve human, animal, and environmental health. Further, the existing spacing system for fish farms requires reconsideration based not only on knowledge of hydrodynamics and human activities but also based on information about fish movements. Unfortunately, the development of effective siting systems may be impeded by the expected increase in the farming industry and the large-scale movement patterns of many fish species along the coast.

Since the existing knowledge about pathogen transfer in Mediterranean aquaculture is sparse, there should be a greater focus on health monitoring of farmed fish as well as on prevention of escapes. Escape incidents may be reduced by improving cage technology and operational routines. Improved routines for reporting escape incidents and infectious episodes would also contribute to improved management. Management agreements among neighbouring farms are also essential tools for risk mitigation (Gustafson et al. 2007), especially if escapees are exposed to prophylactic or therapeutic treatment that could influence the health of the consumers. Finally, future risk assessments for aquaculture management should be improved, and biological interaction among farmed stocks, escapees and wild fish populations should be taken into account. In conclusion, preventive strategies, contingency plans and mitigation measures, as well as spatial planning, which take into account the risk of disease transmission to wild populations and fishing grounds, are essential for sustainable development of Mediterranean aquaculture. Because Mediterranean aquaculture is poorly and non-uniformly regulated (Chapela-Perez \& Ballesteros 2011), future management measures should be made mandatory under governmental regulations, and should be supported by local, regional or international legislation.

Acknowledgements. The study was financed by the EUproject 'Prevent Escape' (project number: 226885; www. preventescape.eu) and by the 'FatFish' project from the Spanish Ministry of Science and Innovation (CTM200914362-C02-01).

\section{LITERATURE CITED}

Alvarez-Pellitero P, Sitjà-Bobadilla A (1993) Pathology of Myxosporea in marine fish culture. Dis Aquat Org 17: 229-238

Amundrud TL, Murray AG (2009) Modelling sea lice dispersion under varying environmental forcing in a Scottish sea loch. J Fish Dis 32:27-44

Arechavala-Lopez P, Uglem I, Sanchez-Jerez P, FernandezJover D, Bayle-Sempere JT, Nilsen R (2010) Movements of grey mullet Liza aurata and Chelon labrosus associated with coastal fish farms in the western Mediterranean Sea. Aquacult Environ Interact 1:127-136

Arechavala-Lopez P, Sanchez-Jerez P, Bayle-Sempere J, Fernandez-Jover D, Martinez-Rubio L, Lopez-Jimenez JA, Martinez-Lopez FJ (2011a) Direct interaction between wild fish aggregations at fish farms and fisheries activity at fishing grounds: a case study with Boops boops. Aquacult Res 42:996-1010

> Arechavala-Lopez P, Uglem I, Fernandez-Jover D, BayleSempere JT, Sanchez-Jerez P (2011b) Immediate postescape behaviour of farmed sea bass (Dicentrarchus labrax) in the Mediterranean Sea. J Appl Ichthyol 27: 1375-1378

> Arechavala-Lopez P, Uglem I, Fernandez-Jover D, BayleSempere JT, Sanchez-Jerez P (2012) Post-escape dispersion of farmed sea bream (Sparus aurata L.) and recaptures by local fisheries in the Western Mediterranean Sea. Fish Res 121-122:126-135

Ashley PJ (2007) Fish welfare: current issues in aquaculture. Appl Anim Behav Sci 104:199-235

Athanassopoulou FD, Bouboulis B, Martinsen B (2001) In vitro treatments of deltamethrin against the isopod parasite Anylocra physodes, a pathogen of sea bass Dicentrarchus labrax L. Bull Eur Assoc Fish Pathol 21:26-29

Balebona MC, Andreu MJ, Bordas A, Zorilla I, Moringo M, Borrego JJ (1998) Pathogenicity of Vibrio alginolyticus for cultured gilt-head sea bream (Sparus aurata L.). Appl Environ Microbiol 64:4269-4275 
Bouboulis D, Athanassopoulou F, Tyrpenou A (2004) Experimental treatments with diflubenzuron and deltamethrin of sea bass, Dicentrarchus labrax L., infected with the isopod, Ceratothoa oestroides. J Appl Ichthyol 20: 314-317

Bondad-Reantaso MG, Subasinghe RP (2008) Meeting the future demand for aquatic food through aquaculture: the role of aquatic animal health. In: Tsukamoto K, Kawamura T, Takeuchi T, Beard TD Jr, Kaiser MJ (eds) Fisheries for global welfare and environment, 5th World Fisheries Congress. Terrapub, Tokyo, p 197-207

Breuil G, Pepin JFP, Boscher S, Thiery R (2002) Experimental vertical transmission of nodavirus from broodfish to eggs and larvae of the sea bass, Dicentrarchus labrax (L.). J Fish Dis 25:697-702

Butler JRA (2002) Wild salmonids and sea louse infestations on the west coast of Scotland: sources of infection and implications for the management of marine salmon farms. Pest Manag Sci 58:595-608

Cardia F, Lovatelli A (2007) A review of cage aquaculture: Mediterranean Sea. In: Halwart M, Soto D, Arthur JR (eds) Cage aquaculture - regional reviews and global overview. FAO Fish Tech Pap 498. FAO, Rome, p 156-187

Castric J, Thiéry R, Jeffroy J, de Kinkelin P, Raymond JC (2001) Sea bream Sparus aurata, an asymptomatic contagious fish host for nodavirus. Dis Aquat Org 47:33-38

Chapela-Perez R, Ballesteros M (2011) Procedures for site selection, regulatory schemes and EIA procedures in the Mediterranean. In: Borg JA, Crosetti D, Massa F (eds) Site selection and carrying capacity in Mediterranean marine aquaculture: key issues (WGSC-SHoCMed). 35th session, General Fisheries Commission for the Mediterranean (GFCM), Rome, p 91-136

Colorni A, Diamant A (1992) Pathology in mariculture: specific problems and research in Israel. Isr J Aquacult Bamidgeh 44:140-141

Colorni A, Diamant A, Eldar A, Kvitt H, Zlotkin A (2002) Streptococcus iniae infections in Red Sea cage-cultured and wild fishes. Dis Aquat Org 49:165-170

DAFF (Department of Agriculture, Fisheries and Forestry) (2000) Aquaplan zoning policy guidelines. Department of Agriculture, Fisheries and Forestry, Canberra

> Diamant A, Banet A, Ucko M, Colorni A, Knibb W, Kvitt H (2000) Mycobacteriosis in wild rabbitfish Siganus rivulatus associated with cage farming in the Gulf of Eilat, Red Sea. Dis Aquat Org 39:211-219

Diamant A, Colorni A, Ucko M (2004) Gulf of Eilat monitoring and research program - International Expert Committee (IET) recommendations. Monitoring program of mortality and disease in wild fish populations in the Gulf of Eilat, northern Red Sea. IET Recommendation No. 22, Report for the Ministries of Infrastructure, Environment and Agriculture

Diamant A, Colorni A, Ucko M (2007) Parasite and disease transfer between cultured and wild coastal marine fish. CIESM Workshop Monogr 32:49-54

Evans JJ, Klesius PH, Gilbert PM, Shoemaker CA and others (2002) Characterization of $\beta$-haemolytic group B Streptococcus agalactiae in cultured sea bream, Sparus auratus L., wild mullet, Liza kluzingeri (Day), in Kuwait. J Fish Dis 25:505-513

FAO (Food and Agriculture Organization of the United Nations) (2011) The State of World Fisheries and Aquaculture (SOFIA), 2010. Fisheries Department, FAO, Rome
Fernandez-Jover D, Faliex E, Sanchez-Jerez P, Sasal P, Bayle-Sempere JT (2010) Coastal fish farming does not affect the total parasite communities of wild fish in SW Mediterranean. Aquaculture 300:10-16

> Ford JS, Myers RA (2008) A global assessment of salmon aquaculture impacts on wild salmonids. PLoS Biol 6:e33

> Fouz B, Toranzo AE, Milan M, Amaro C (2000) Evidence that water transmits the disease caused by the fish pathogen Photobacterium damselae subsp. damselae. J Appl Microbiol 88:531-535

Frazer LN (2009) Sea cage aquaculture, sea lice, and declines of wild fish. Conserv Biol 23:599-607

Graham DA (2005) Serological testing of wild salmonids for antibodies to Salmonid Alphaviruses. DIPNET Newsletter 9. Available at www.revistaaquatic.com/DIPNET/ newsletters/index.asp (accessed 1 March 2013)

> Gustafson LL, Ellis SK, Beattie MJ, Chang BD and others (2007) Hydrographics and the timing of infectious salmon anemia outbreaks among Atlantic salmon (Salmo salar L.) farms in the Quoddy region of Maine, USA and New Brunswick, Canada. Prev Vet Med 78:35-56

- Hansen LA, Dale T, Damsgård B, Uglem I, Aas K, Bjørn PA (2008) Escape related behaviour of Atlantic cod (Gadus morhua L.) in a simulated farm situation. Aquacult Res 40:26-34

> Heuch PA, Mo TA (2001) A model of salmon louse production in Norway: effects of increasing salmon production and public management measures. Dis Aquat Org 45: 145-152

Heuch PA, Jansen PA, Hansen H, Sterud E, MacKenzie K, Haugen P, Hemmingsen W (2011) Parasite faunas of farmed cod and adjacent wild cod populations in Norway: a comparison. Aquacult Environ Interact 2:1-13

Horbowy J, Podolska M (2001) Modelling infection of Baltic herring (Clupea harengus membras) by larval Anisakis simplex. ICES J Mar Sci 58:321-330

Jackson D, Drumm A, McEvoy S, Jensen $\varnothing$ and others (2012) A pan-European evaluation of the extent, causes and cost of escape events from sea-cage fish farming. In: Dempster $\mathrm{T}$ (ed) PREVENT ESCAPE Project Compendium. Chapter 2. Commission of the European Communities, 7th Research Framework Programme, p 29-48

> Jensen Ø, Dempster T, Thorstad EB, Uglem I, Fredheim A (2010) Escapes of fishes from Norwegian sea-cage aquaculture: causes, consequences and prevention. Aquacult Environ Interact 1:71-83

Johansen LH, Jensen I, Mikkelsen H, Bjørn PA, Jansen PA, Bergh $\varnothing$ (2011) Disease interaction and pathogens exchange between wild and farmed fish populations with special reference to Norway. Aquaculture 315:167-186

> Johnsen BO, Jensen AJ (1994) The spread of furunculosis in salmonids in Norwegian rivers. J Fish Biol 45:47-55

> Kennedy CR, Fitch DJ (1990) Colonization, larval survival and epidemiology of the nematode Anguillicola crassus, parasitic in the eel, Anguilla anguilla, in Britain. J Fish Biol 36:117-131

Krkošek M (2010) Host density thresholds and disease control for fisheries and aquaculture. Aquacult Environ Interact 1:21-32

$>$ Krkošek M, Lewis MA, Volpe JP (2005) Transmission dynamics of parasitic sea lice from farm to wild salmon. Proc R Soc Lond B Biol Sci 272:689-696

$>$ Kvitt H, Colorni A (2004) Strain variation and geographic endemism in Streptococcus iniae. Dis Aquat Org 61: $67-73$ 
Le Breton AD (1999) Mediterranean finfish pathologies: present status and new developments in prophylactic methods. Bull Eur Assoc Fish Pathol 19:250-253

Lyngstad TM, Jansen PA, Brun E, Sindre H (2008) Epidemiological investigations of infectious salmon anaemia (ISA) outbreaks in Norway 2003-2005. Prev Vet Med 84: 213-227

Mardones FO, Perez AM, Carpenter TE (2009) Epidemiologic investigation of the re-emergence of infectious salmon anemia virus in Chile. Dis Aquat Org 84:105-114

Marine Scotland (2010) Management area maps: April 2010. Available at www.scotland.gov.uk/Topics/marine/seamanagement/marineact (accessed 1 March 2013)

McVicar AH (2004) Management actions in relation to the controversy about salmon lice infections in fish farms as a hazard to wild salmonid populations. Aquacult Res 35: 751-758

> Meyer FP (1991) Aquaculture disease and health management. J Anim Sci 69:4201-4208

Mladineo I (2002) A case study of pasteurellosis epizootic and heavy parasite infection in Adriatic. In: Galeotti M (ed) Recent findings on the development of new vaccines against fish pasteurellosis. Book of Abstracts. Conference of the European Association of Fish Pathologists, November 2002, Udine, p 38

Mladineo I (2003) Life cycle of Ceratothoa oestroides, a cymothoid isopod parasite from sea bass Dicentrarchus labrax and sea bream Sparus aurata. Dis Aquat Org 57: 97-101

Mladineo I, Maršić-Lučić J (2007) Host switching of Lamellodiscus elegans (Monogenea: Monopisthocotylea) and Sparicotyle chrysophrii (Monogenea: Polyopisthocotylea) between cage-reared sparids. Vet Res Commun 31: 153-160

Mladineo I, Valić D (2002) The mechanisms of infection of the buccal isopod Ceratothoa oestroides (Risso, 1836), under experimental conditions. Bull Eur Assoc Fish Pathol 22:304-310

Mladineo I, Šegvić T, Grubišić L (2009) Molecular evidence for the lack of transmission of the monogenean Sparicotyle chrysophrii (Monogenea, Polyopisthocotylea) and isopod Ceratothoa oestroides (Crustacea, Cymothoidae) between wild bogue (Boops boops) and cage-reared sea bream (Sparus aurata) and sea bass (Dicentrarchus labrax). Aquaculture 295:160-167

Mladineo I, Perić M, Šegvić T, Dobričić N (2010) Scarcity of parasite assemblages in the Adriatic-reared European sea bass (Dicentrarchus labrax) and sea bream (Sparus aurata). Vet Parasitol 174:131-138

Mladineo I, Šegvić T, Petrić M (2011) Do captive conditions favor shedding of parasites in the reared Atlantic bluefin tuna (Thunnus thynnus)? Parasitol Int 60:25-33

> Murray AG (2009) Using simple models to review the application and implications of different approaches used to simulate transmission of pathogens among aquatic animals. Prev Vet Med 88:167-177

Murray AG, Peeler EJ (2005) A framework for understanding the potential for emerging diseases in aquaculture. Prev Vet Med 67:223-235

Murray AG, O'Callaghan M, Jones B (2003) A model of spatially evolving herpesvirus epidemics causing mass mortality in Australian pilchard Sardinops sagax. Dis Aquat Org 54:1-14

Naylor R, Hindar K, Fleming IA, Goldburg R and others (2005) Fugitive salmon: assessing the risks of escaped fish from net-pen aquaculture. BioScience 55:427-437

Noga JE (2000) Fish disease: diagnosis and treatment. Iowa State University Press, Ames, IA

Nowak BF (2007) Parasitic diseases in marine cage culture an example of experimental evolution of parasites? Int J Parasitol 37:581-588

> Øines Ø, Simonsen JH, Knutsen JA, Heuch PA (2006) Host preference of adult Caligus elongatus Nordmann in the laboratory and its implications for Atlantic cod aquaculture. J Fish Dis 29:167-174

Panzarin V, Fusaro F, Monne I, Cappellozza E and others (2012) Molecular epidemiology and evolutionary dynamics of betanodavirus in southern Europe. Infect Genet Evol 12:63-70

> Papapanagiotou EP, Trilles JP (2001) Cymothoid parasite Ceratothoa parallela inflicts great losses on cultured gilthead sea bream Sparus aurata in Greece. Dis Aquat Org 45:237-239

> Peeler E, Thrush M, Paisley L, Rodgers C (2006) An assessment of the risk of spreading the fish parasite Gyrodactylus salaris to uninfected territories in the European Union with the movement of live Atlantic salmon (Salmo salar) from coastal waters. Aquaculture 258:187-197

Piper RG, McElwain IB, Orme LE, McCraren JP, Fowler LG, Leonard JR (1982) Fish hatchery management. US Department of the Interior, Fish and Wildlife Service, Washington, DC

> Plarre H, Devold M, Snow M, Nylund A (2005) Prevalence of infectious salmon anaemia virus (ISAV) in wild salmonids in western Norway. Dis Aquat Org 66:71-79

Rae GH (2002) Sea louse control in Scotland, past and present. Pest Manag Sci 58:515-520

Raynard R, Wahli T, Vatsos I, Mortensen S (2007) Review of disease interactions and pathogen exchange between farmed and wild finfish and shellfish in Europe (DIPNET). Available at www.revistaaquatic.com/DIPNET/ docs/index.asp (accessed 1 March 2013)

> Redondo MJ, Palenzuela O, Alvarez-Pellitero P (2004) Studies on transmission and life cycle of Enteromyxum scophthalmi (Myxozoa), an enteric parasite of turbot Scophthalmus maximus. Folia Parasitol 51:188-198

Revie C, Dill L, Finstad B, Todd CD (2009) Salmon aquaculture working group report on sea lice. Salmon Aquaculture Dialogue. Available at http://wwf.worldwildlife.org/ site/PageNavigator/SalmonSOIForm (accessed 1 March 2013)

Rigos G, Christophilogiannis P, Yiagnisi M, Andriopoulou A, Koutsodimou M, Nengas I, Alexis M (1999) Myxosporean infections in Greek mariculture. Aquacult Int 7:361-364

Rodgers C, Basurco B (eds) (2009) The use of veterinary drugs and vaccines in Mediterranean aquaculture. Options Méditerranéennes, Ser A (Séminaires Méditerranéens) No. 86. CIHEAM, Zaragoza, p 155-176

Romalde JL, Magariños B, Lores F, Toranzo AE (1999) Assessment of a magnetic bead-EIA based kit for rapid diagnosis of fish pasteurellosis. J Microbiol Methods 38: 147-154

Ruiz GM, Rawlings TK, Dobbs FC, Drake LA, Mullady T, Huq A, Colwell RR (2000) Global spread of microorganisms by ships. Nature 408:49-50

Salama NKG, Murray AG (2011) Farm size as a factor in hydrodynamic transmission of pathogens in aquaculture fish production. Aquacult Environ Interact 2:61-74

Sanchez-Jerez P, Fernandez-Jover D, Uglem I, ArechavalaLopez P and others (2011) Coastal fish farms and poten- 
tial effects on fisheries. In: Bortone SA, Pereira Brandini F, Fabi G, Otake S (eds) Artificial reefs for fisheries management. CRC Press, Boca Raton, FL, p 187-208

Sasal P, Desdevises Y, Durieux E, Lenfant P, Romans P (2004) Parasites in marine protected areas: success and specificity of monogeneans. J Fish Biol 64:370-379

Scottish Executive (2000) Final report of the joint government/industry working group on ISA. Scottish Executive, Aberdeen

Sitja-Bobadilla A, Alvarez-Pellitero P (1993) Population dynamics of Sphaerospora dicentrarchi Sitja-Bobadilla et Alvarez-Pellitero, 1992 and S. testicularis Sitja-Bobadilla et Alvarez-Pellitero, 1990 (Myxosporea: Bivalvulida) infections in wild and cultured Mediterranean sea bass (Dicentrarchus labrax L.). Parasitology 106:39-45

Subasinghe RP (2009) Disease control in aquaculture and the responsible use of veterinary drugs and vaccines: the issues, prospects and challenges. In: Rodgers C, Basurco $B$ (eds) The use of veterinary drugs and vaccines in Mediterranean aquaculture. Options Méditerranéennes, Ser A (Séminaires Méditerranéens) No. 86. CIHEAM, Zaragoza, p 5-11

Subasinghe RP, McGladdery SE, Hill BJ (2004) Surveillance and zoning for aquatic animal diseases. FAO Fish Tech Pap 451. FAO, Rome

Thorstad EB, Fleming IA, McGinnity P, Soto D, Wennevik V, Whoriskey $F$ (2008) Incidence and impacts of escaped

Editorial responsibility: Marianne Holmer,

Odense, Denmark farmed Atlantic salmon Salmo salar in nature. Nor Inst Nat Res Spec Rep 36:1-110

> Toledo-Guedes K, Sanchez-Jerez P, Mora-Vidal J, Girard D, Brito A (2012) Escaped introduced sea bass (Dicentrarchus labrax) infected by Sphaerospora testicularis (Myxozoa) reach maturity in coastal habitats off Canary Islands. PSZN I: Mar Ecol 33:26-31

Toranzo AE, Magariños B, Romalde JL (2005) A review of the main bacterial fish diseases in mariculture systems. Aquaculture 246:37-61

Ucko M, Colorni A, Kvitt H, Diamant A, Zlotkin A, Knibb WR (2002) Strain variation in Mycobacterium marinum fish isolates. Appl Environ Microbiol 68:5281-5287

Uglem I, Bjørn PA, Dale T, Kerwath S and others (2008) Movements and spatiotemporal distribution of escaped farmed and local wild Atlantic cod (Gadus morhua L.). Aquacult Res 39:158-170

> Uglem I, Dempster T, Bjørn PA, Sanchez-Jerez P, Økland F (2009) High connectivity of salmon farms revealed by aggregation, residence and repeated movements of wild fish among farms. Mar Ecol Prog Ser 384:251-260

> Uglem I, Bjørn PA, Mitamura H, Nilsen R (2010) Spatiotemporal distribution of coastal and oceanic Atlantic cod Gadus morhua sub-groups after escape from a farm. Aquacult Environ Interact 1:11-19

Wootten R (1989) The parasitology of teleosts. In: Roberts RJ (ed) Fish pathology. Baillière Tindall, London, p 242-288

Submitted: May 7, 2012; Accepted: February 1, 2013 Proofs received from author(s): February 24, 2013 